Marko Miljković $^{1}$

Sanja Filipović ${ }^{2}$

Svetozar Tanasković ${ }^{3}$
JEL: G21, G29

DOI: 10.5937/industrija41-5096

UDK:330.13:336.71(497.11)"2008/2012";

338.124.4(100)

Original Scientific Paper

\title{
Profitability of Serbian Banking Sector During Global Economic Crisis ${ }^{4}$
}

\author{
Article history \\ Received: 29 August 2013 \\ Sent for revision: 1 October 2013 \\ Received in revised form: 17 November 2013 \\ Accepted: 23 November 2013 \\ Available online: 6 December 2013
}

\begin{abstract}
The aim of the paper is to identify the main factors which contributed to decline of profitability in Serbian banking sector during the period of global economic crisis. There are presented different theories of banking sector profitability and results of scientifically significant empirical researches from economic literature. Following ratios were used as measure of profitability: return on assets (ROA), return on equity (ROE), net interest gain to total revenue, net fees and commissions gain to total revenue, and net pre-tax profit/loss to total revenue ratio. The profitability was analyzed for the whole Serbian banking sector in the period 2008-2012 and particularly for the 15 largest banks according to total assets value in 2012. The empirical analysis indicated that one of the most important factors contributing to high amounts of losses of commercial banks in the previous period includes an increase of net operating expenses, especially expenses on account of a write-off of nonperforming loans (NPL). Furthermore, there were analyzed the dynamics of interest rates and interest spread as a factor with certain impact on profitability of banks. Finally, it is estimated that the prospects for intensive growth of profitability in the banking sector of Serbia in the mid-term are poor.
\end{abstract}

Key words: banking, profitability, non-performing loans, financial crisis.

\footnotetext{
${ }^{1}$ Economics Institute,Belgrade, marko.miljkovic@ecinst.org.rs

${ }^{2}$ Economics Institute, Belgrade, sanja.filipovic@ecinst.org.rs

${ }^{3}$ University of Belgrade, Faculty of Economics, tanaskovic@ekof.bg.ac.rs

${ }^{4}$ This paper is a part of research project 179001 and 47009 financed by the Ministry of Science and Technological Development of the Republic of Serbia.
} 
Miljković M. et al.: Profitability of Serbian Banking Sector during global economic crisis

\section{Profitabilnost bankarskog sektora Srbije tokom svetske ekonomske krize}

Apstrakt: Osnovni cilj rada je da se utvrde glavni faktori koji su doprineli padu profitabilnosti u bankarskom sektoru Srbije u periodu svetske ekonomske krize. $U$ radu su predstavljene različite teorije profitabilnosti bankarskog sektora iz ekonomske literature i rezultati naučno značajnih empirijskih istraživanja. Profitabilnost je merena sledećim indikatorima: stopa prinosa na imovinu (ROA), stopa prinosa na kapital (ROE), stopa neto dobiti od kamata, stopa neto dobiti od naknada i provizija i stopa neto dobiti pre oporezivanja. Analiza je sprovedena na nivou celog bankarskog sektora za period 20082012. godine i posebno za 15 najvećih banaka po vrednosti ukupne aktive $u$ 2012. godini. Empirijska analiza je pokazala da jedan od najznačajnijih faktora koji su doprineli visokim gubicima poslovnih banaka predstavlja rast neto operativnih rashoda, posebno, rashoda na ime otpisa problematičnih kredita. Pored toga, u radu je analizirana dinamika kamatnih stopa i kamatne marže sa izvesnim uticajima na profitabilnost banaka. Konačno, procenjeno je se da su izgledi za intezivan rast profitabilnosti $u$ bankarskom sektoru Srbije $u$ srednjem roku skromne.

Ključne reči: bankarski sektor, profitabilnost, problematični krediti, finansijska kriza.

\section{Introduction}

The current global economic crisis initiated by the escalation of financial crisis in 2008, revives the issue of financial stability and sensitivity level of bank profit to business cycle (Bolt, Haan, Hoeberichts, Oordt \& Swank, 2010).

Financial stability is widely accepted as a situation in which financial system is capable of simultaneously performing its three key functions in a satisfactory way, including the following ones: (I) efficient and smooth facilitation of the inter-temporal allocation of resources from the surplus economic units to the deficit economic units, (II) managing the forward looking financial risks with appropriate pricing and (III) to be prepared all the time to absorb the financial and real economic surprises and shocks (Swamy, 2013).

Counter-party risk of financial stability is an outcome directly related to nonperforming assets. Having in mind that better asset quality aids improvement in profitability, it is crucial to find what factors affect bank profitability and what lessons can be drawn in the context of bank asset quality and profitability. The Basel Committee on Banking Supervision set forth an update of guidelines for capital and banking regulations. Basel III proposes many new capital, leverage, and liquidity standards in order to strengthen regulation, supervision, and risk management in the banking sector (Lee \& Hsieh, 2013). 
Bank profitability can be assessed at the micro and macro levels or as a function of internal variables or bank management functions and external determinants which represent macroeconomic and legal environment. In the case of internal variables, there is evident a positive relationship between capital and profitability (Altunbas, Carbo, Gardener \& Molyneux, 2007; Iannotta, Nocera \& Sironi, 2007). On the other hand, there are some papers which came to the opposite results (Agusman, Monroe, Gasbarro \& Zumwalt, 2008; Agoraki, Delis \& Pasiouras, 2011). Alper \& Anbar (2011) showed that size of total assets and non-interest incomes have a positive and significant effect on bank profitability. However, size of credit portfolio and loans under follow-up have a significantly negative impact on bank profitability.

In the case of external factors, Albertazzi \& Gambacorta (2009) report a significant relation between real GDP growth and bank profitability. Analysing key determinants of bank profitability in South European region, Athanasoglou, Delis \& Staikouras (2006) found that inflation has a strong effect on profitability, while bank profits are not significantly affected by real GDP per capita fluctuations. Athanasoglou, Brissimis \& Delis (2008) found a positive relation between the output gap and the profitability of a panel of Greek banks. Considering banking regulations, heavier regulatory costs would be imposed on the banks with riskier characteristics (e.g. lower capital ratio, larger size of assets size, higher loan ratio etc.). Thus, the profitability of these banks would be affected more adversely than the banks with safer characteristics (Lee, 2013).

Profitability of banking sectors is mainly related to economies of scale, efficiency of management (X-efficiency) and concentrations. According to Goddard, Molyneux \& Wilson (2004), scale economies are evident at low asset size levels, but become exhausted as size increases. The mentioned authors found that this relationship is negative for Germany and Spain and positive for the UK. Testing the determinants of the profitability of the US banks, Hoffmann (2011) showed that economies of scale do not occur if one takes into consideration the size of the bank. It is recognized that efficient-structure banks with superior management or production technologies have lower costs and therefore higher profits. Considering concentration as the relevant factor of profitability, there is positive relationship due to monopolistic behaviour of banks with increased market share (Athanasoglou et al, 2006).

The profitability of banks is a very important indicator of the strength of financial system and its development, especially in Central and Eastern European (CEE) countries, where financial systems are bank-centric (e.g. 2012 data regarding the share of the total assets of the banking sector in GDP - Slovenia 126\%, Czech Republic 124\%, Hungary 108\%, Serbia 94\%, Albania 90\%, Bosnia and Herzegovina 87\%). 
The profitability of Western European banks was directly affected by the financial crisis. The crisis did also affect banks in different regions, but the regional effects seem to differ both with respect to timing and strength. While Western European banks had suffered severely (Lindblom, Olsson \& Willesson, 2011), banks in CEE countries appear to be better on average. However, CEE banks were facing a significant decrease in their overall profitability in 2009 (Radulescu \& Tanascovici, 2012). On the other hand, banks in CEE region continue to benefit from growth opportunities and margins that are significantly higher than in Western Europe. The average return on equity (ROE) ratio in CEE banking sectors stood at 16\% in 2012, while in Western Europe the average ROE just turned into barely positive area (Raiffeisen Research, 2013). In CEE region, well-diversified banks can earn more than their cost of capital, while Western European banking sectors currently do not offer comparable earning potentials.

The Serbian banking sector was well prepared for the first and the second wave of global economic crisis, having in mind high level of capitalization of commercial banks and proactive measures of National Bank (Filipović, 2010; Miljković, Filipović \& Tanasković, 2013). This resulted in positive net pre-tax result at the level of the banking sector as a whole during the entire observed period from 2008 until 2012.

This paper contributes to empirical research in several ways. First, the existing literature has drawn a lot of attention on Western European or U.S. cases (Fernández, Maudos \& Pérez, 2007; Carbo, Humphrey, Maudos \& Molyneux, 2009), while South Eastern countries including Serbia has not earned enough discussions. Thus, the purpose of this paper is to examine the profitability of Serbian banks in the period of current global economic crisis. Secondly, most studies focus mainly on the relationship between profitability and factors such as capital, concentration, bank size, etc. while only few studies of citable significance have dealt with the problems of non-performing loans (NPL). Having in mind the lack of sufficient literature on this relation this paper discusses profitability in context of NPL and five selected profitability ratios.

\section{Methodological Framework for Research}

Economic literature uses numerous ways of measuring profitability in the banking sector. In order to determine the level of profitability in the banking sector in Serbia, in this paper there were used most commonly applied profitability measures. In first line, there were analysed absolute values of the following indicators:

- net pre-tax profit of the banks operating with profit,

- net loss of the banks operating with loss and 
- $\quad$ net pre-tax result of the sector as a whole.

Thereby, net pre-tax profit was calculated as a sum of net pre-tax profits of all the banks operating with profit in the banking sector in Serbia, while net loss was calculated as a sum of net losses of all the banks operating with loss. On the other hand, net pre-tax result represents a sum of net pre-tax results of all the banks operating in the banking sector in Serbia.

The paper additionally pays attention to the main cause of declining net pretax profit, i.e. to non-performing loans. In accordance with the internationally accepted definition, "a non-performing loan implies the status of outstanding debt on individual loan: (I) where the payment of principal or interest is 90 or more days past due after the original maturity date, (II) where at least 90 days of interest payments were added to the loan balance, capitalised, refinanced or delayed by agreement and (III) where payments are less than 90 days overdue, but the bank has assessed that the borrower's repayment ability has deteriorated and doubts that the payments will be made in full" (National Bank of Serbia, 2012). There were also analyzed the dynamics of interest rates and interest spread as a very important factors of profitability of banks.

Furthermore, there were analysed relative measures of profitability, i.e. the following profitability ratios:

- return on assets ratio (ROA),

- return on equity ratio (ROE),

- net interest gain to total revenue ratio,

- net fees and commissions gain to total revenue ratio and

- net pre-tax result to total revenue ratio.

Return on assets ratio represents the relation between net pre-tax profit and average assets measuring the efficiency of the assets management of the banks, i.e. indicating how much net pre-tax profit is generated per monetary unit of assets (Monea, 2011). It was calculated according to the following formula:

$R O A=\frac{n e t \text { pretax profit }}{\underline{\text { (total assets at the beginning of the period }+ \text { total assets at the end of the period })}}$

Return on equity ratio, on the other hand, represents the relation between net pre-tax profit and average assets measuring the profitability of the shareholders investments (Monea, 2011). It was calculated according to the followingformula:

$R O E=\frac{n e t \text { pretax prof it }}{\frac{(\text { total equity at the beginning of the period total equity at the end of the period })}{2}}$

Net interest gain margin was calculated as a share of net interest income in total revenues: 
Miljković M. et al.: Profitability of Serbian Banking Sector during global economic crisis

net interest gain margin $=\frac{(\text { interest income-interest expense })}{\text { total revenue }} * 100 \%$

while net fees and commissions gain margin was calculated as a share of net fees and commissions income in total revenues:

net fees and commissions gain margin $=\frac{(\text { fees and commissions income-fees and commissions expense })}{\text { total } \text { ceverue }} * 100 \%$

Consequently, net pre-tax profit margin represents the relation between net pre-tax profit and total revenues and was calculated according to the following formula:

net pretax profit margin $=\frac{\text { net pretax profit }}{\text { total revenue }} * 100 \%$

The analysis was in first line related to the banking sector as a whole. Nevertheless, there were analyzed profitability indicators for the 15 largest commercial banks according to total assets criterion (Table 1).

Table 1. The 15 largest banks in the banking sector in Serbia as of $31^{\text {st }}$ December 2012 according to total assets criterion

\begin{tabular}{|c|l|l|r|}
\hline Nr. & \multicolumn{1}{|c|}{ Name } & \multicolumn{1}{|c|}{$\begin{array}{c}\text { Abbreviation in } \\
\text { illustrations }\end{array}$} & $\begin{array}{c}\text { Value of total assets as of 31 } \\
\text { December 2012, in RSD millions }\end{array}$ \\
\hline 1 & Banca Intesa & INTESA & 413,330 \\
\hline 2 & Komercijalna Banka & KOMERCIJALNA & 324,188 \\
\hline 3 & Unicredit Bank & UNICREDIT & 243,554 \\
\hline 4 & $\begin{array}{l}\text { Societe Generale } \\
\text { Banka }\end{array}$ & SOCIETE & 202,925 \\
\hline 5 & Raiffeisen Bank & RAIFFEISEN & 199,590 \\
\hline 6 & Eurobank & EUROBANK & 168,927 \\
\hline 7 & $\begin{array}{l}\text { Hypo Alpe-Adria } \\
\text { Bank }\end{array}$ & HYPO & 168,480 \\
\hline 8 & AlK Banka & AIK & 154,352 \\
\hline 9 & Vojvođanska Banka & VOJVOĐANSKA & 104,064 \\
\hline 10 & Sberbank & SBERBANK & 101,884 \\
\hline 11 & Alpha Bank & ALPHA & 91,236 \\
\hline 12 & Erste Bank & ERSTE & 80,690 \\
\hline 13 & Procredit Bank & PROCREDIT & 67,826 \\
\hline 14 & $\begin{array}{l}\text { Credit Agricole } \\
\text { Bank }\end{array}$ & AGRICOLE & 63,791 \\
\hline 15 & Piraeus Bank & PIRAEUS & 61,888 \\
\hline
\end{tabular}

Source: Banking Sector in Serbia - Fourth Quarter Report 2012, National Bank of Serbia 
Considering that the main purpose of the paper is to investigate the profitability level of Serbian banking sector during the economic crisis, the research covers the period from 2008, as the year when the crisis started, till 2012, as the year when the Serbian economy felt the effects of the second wave of economic crisis.

\section{Serbian Banking Sector in the Period 2008-2012}

At the very beginning of the financial and economic crisis in 2008 , the Serbian banking sector achieved a positive net pre-tax result, what was by even $48.9 \%$ higher profit than in 2007. Spill over effects of the global economic crisis on Serbian banking sector were transmitted in 2009, when the net pretax result declined by even $42.7 \%$. In first line, it was a result of an increase of expenses for indirect write-offs of loans, investments and provisions. One of the most important factors contributing to high amounts of net losses of commercial banks in the previous period includes an increase of net operating expenses, especially expenses on account of a write-off of uncollected claims.

The negative impact of global economic crises implied structural damage in the real sector of the Serbian economy, what consequently reflected on the stability of the banking sector. In the Fig. 1, there are presented net changes in credit stock awarded to Serbian enterprises and households by both domestic banks operating on Serbian market and international banks (crossborder credits). It can be noticed that credit stock to enterprises showed signs of severe deterioration in 2009, mainly due to reduced level of cross-border lending. In this and the following years, domestic banks took over the function of the only lender on the market, which made them entirely exposed to the risk of increased insolvency of the economy.

Serbian government introduced subsidies for new credit lines as an instrument for stimulation of credit activity, what achieved its effects in 2010 and 2011. However, very soon such a way of boosting credit growth became fiscally unsustainable due to large amounts of fiscal deficit. Considering reduced subsidies funds, as well as second wave of economic crisis, the credit stock decreased again in 2012. 
Miljković M. et al.: Profitability of Serbian Banking Sector during global economic crisis

Figure 1. Changes in credit stock in Serbia during 2008-2012, in EUR millions

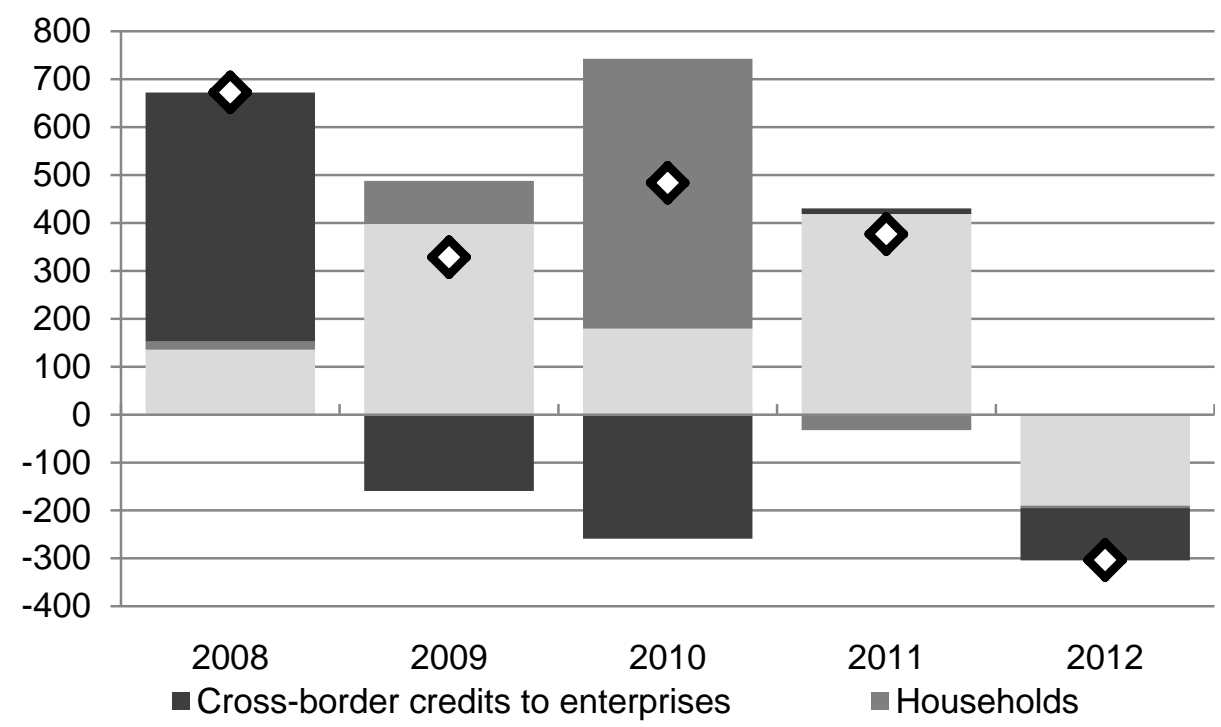

Source: Authors' calculations based on data from NBS monetary sector statistics

The level of non-performing loans (NPL) was continuously increasing during the entire observed period from 2008 till 2012 (Fig. 2). Such an increase in NPL was a direct consequence of fast credit growth in the pre-crisis period, considering that large credit lines created excessive burden to the real sector which fell into recession. The share of total NPL in total loans amounted to 18.6 in 2012, what was by 7.3 higher than in 2008. Unlike households which obviously most regularly pay back their credits, enterprises are in quite worse position, what is particularly related to entrepreneurs, considering their share of NPL in total loans amounting to even $28 \%$. 
Figure 2. Share of NPL in total loans in Serbian banking sector during 20082012 , in \%

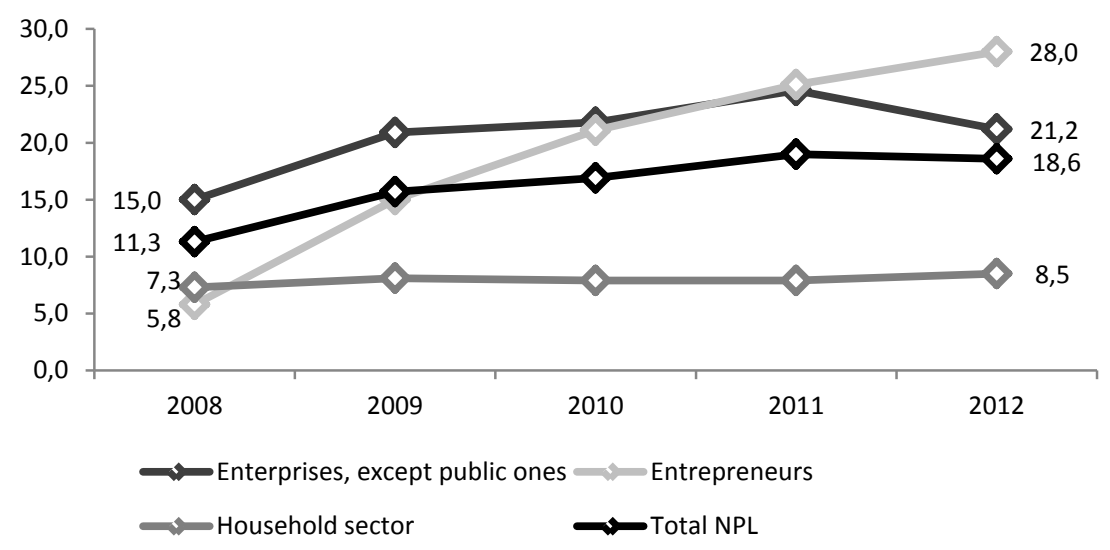

Source: Banking Sector in Serbia - Quarter Reports, National Bank of Serbia

Due to this negative trend, commercial banks started to allocate larger amounts of capital for the purpose of securing problematic credits. Negative effects of NPL on banking sector in Serbia is a typical case of loophole hypothesis defined by Waheed and Younus (2010), when credit crunch decreases the ability of real economy to finance its operations and service its credits which then increase NPL, what leads to harder conditions for new lending and reducing of growth.

In contrast to the poor result in 2009 , the banking sector achieved a positive profit in 2009 and 2010 (Fig. 3). On the other hand, the net pre-tax profit attained a record-low level in 2011 . However, such a bad result was caused by an increase of net expenses arising from the write-off of loans, investments and provisions registered by only one state-owned bank - (Nova) Agrobanka. When excluding the losses of (Nova) Agrobanka from the net pre-tax result of the banking sector as a whole, the sector experienced even growth of net pretax profit as compared with the year before. A similar situation happened also in 2012. Nevertheless, such a result could be quite better considering the enormous level of net losses of another state-owned bank - Razvojna Banka Vojvodine (RBV). 
Figure 3. Net pre-tax result of the banking sector in Serbia during 2008-2012, in RSD billions

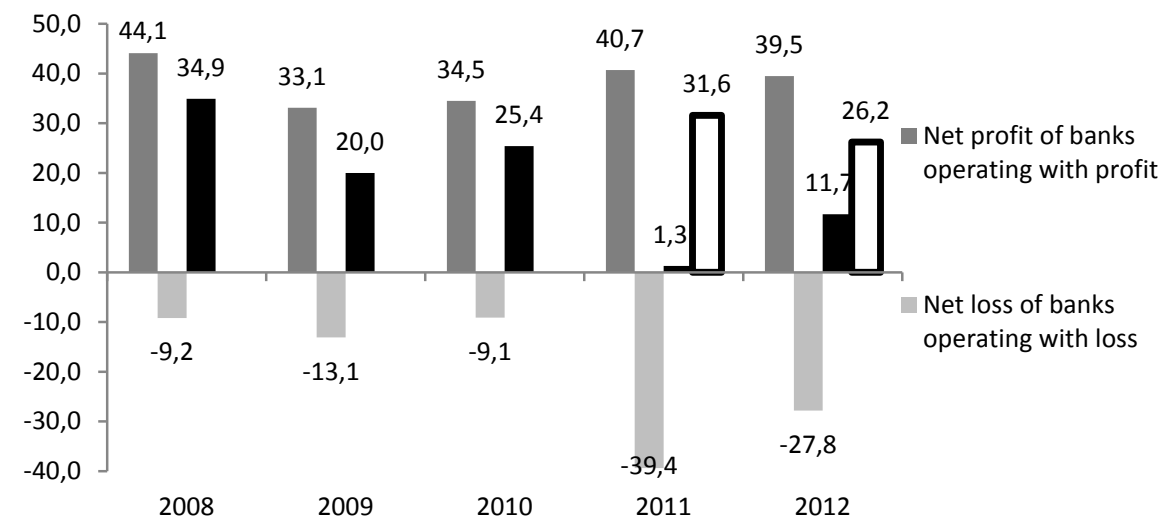

Source: Authors' calculations based on data from balance sheets of commercial banks

The number of banks operating with profit amounted to 21 in 2012 . The distribution of profit is quite concentrated (Fig. 4) considering that even $54.1 \%$ of the total net pre-tax profit was achieved by only three banks in foreign ownership: Banca Intesa, Raiffeisen Banka and Unicredit Bank, while $21.7 \%$ of the total net pre-tax profit was generated by two banks in domestic ownership: Komercijalna Banka (state-owned bank) and AIK Banka (privately owned bank). Other $24.2 \%$ of the total net pre-tax profit was achieved by other 16 banks operating with profit.

Figure 4. Structure of net pre-tax profit in 2012 by commercial banks, in \%

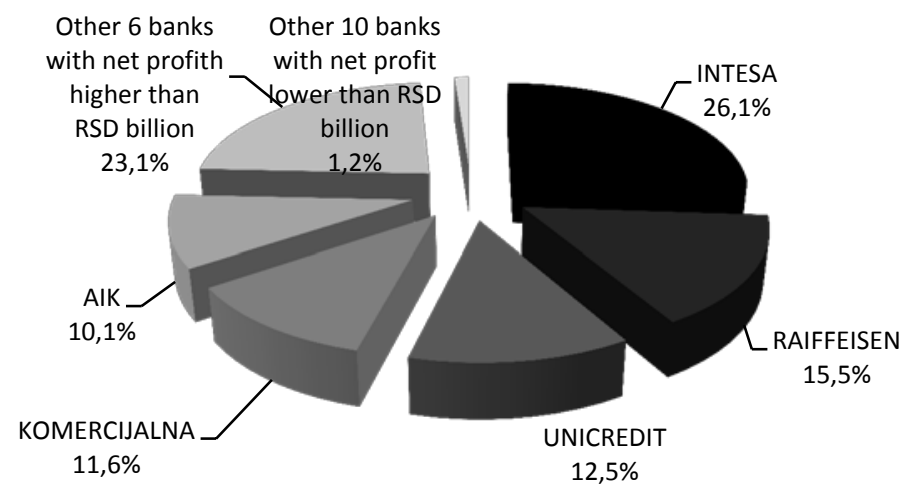

Source: Authors' calculations based on data from balance sheets of commercial banks 
On the other hand, the number of banks operating with losses amounted to 9 in 2012. The distribution of losses is quite more concentrated than the distribution of profit (Fig. 5). Even 52.2\% of the total net loss was achieved by Razvojna Banka Vojvodine, a state-owned bank delicenced by the National Bank of Serbia in April 2013, while $40.3 \%$ of the total net loss was generated by five banks in foreign ownership: NLB Banka, Alpha Bank, Vojvodjanska Banka, Piraeus Bank and OTP Banka. Other 7.5\% of the total net loss was achieved by remaining 5 banks operating with losses lower than RSD billion per commercial bank.

Figure 5. Structure of net loss in 2012 by commercial banks, in \%

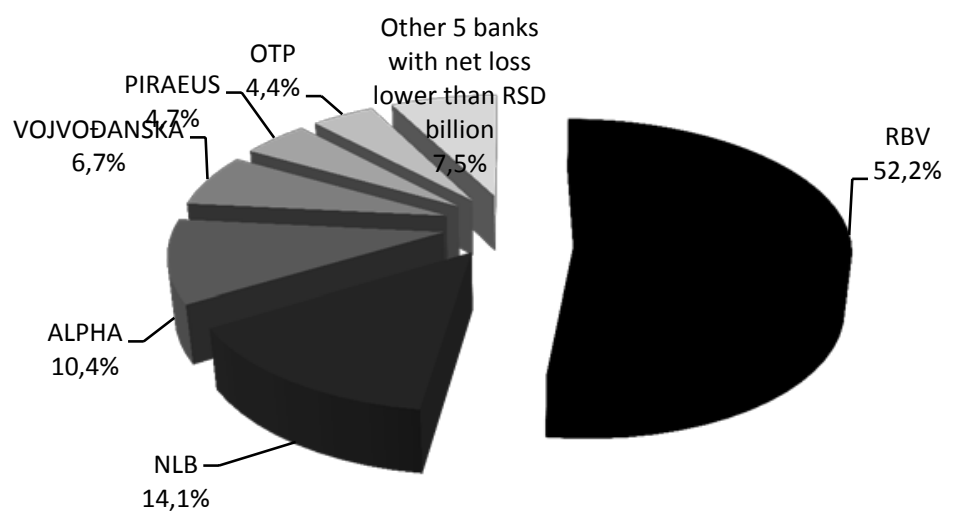

Source: Authors' calculations based on data from balance sheets of commercial banks

Certain impact on declining profitability in the Serbian banking sector during the observed period (2008- 2012), beside non-performing loans, can be attributed to interest rate trends. The average weighted lending interest, calculated as interest income to average interest-bearing assets ratio, amounted to $9.6 \%$ in 2012 , what is by $3.2 \%$ lower than in 2008 . On the other hand, the average weighted deposit interest, calculated as interest expense to average interest-bearing liabilities, amounted to $4.2 \%$ in 2012 , what is by $1.1 \%$ lower than in 2008. Considering quite faster decreasing trend of lending interest rate as compared with deposit one, interest spread, calculated as difference between average weighted interest receivable and average weighted interest payable, was continuously declining during the entire observed period, reaching the level of $5.4 \%$ in 2012, as presented in the Fig. 6. 
Figure 6. Interest rate trends in the banking sector in Serbia during the period from 2008 till 2012, in \%

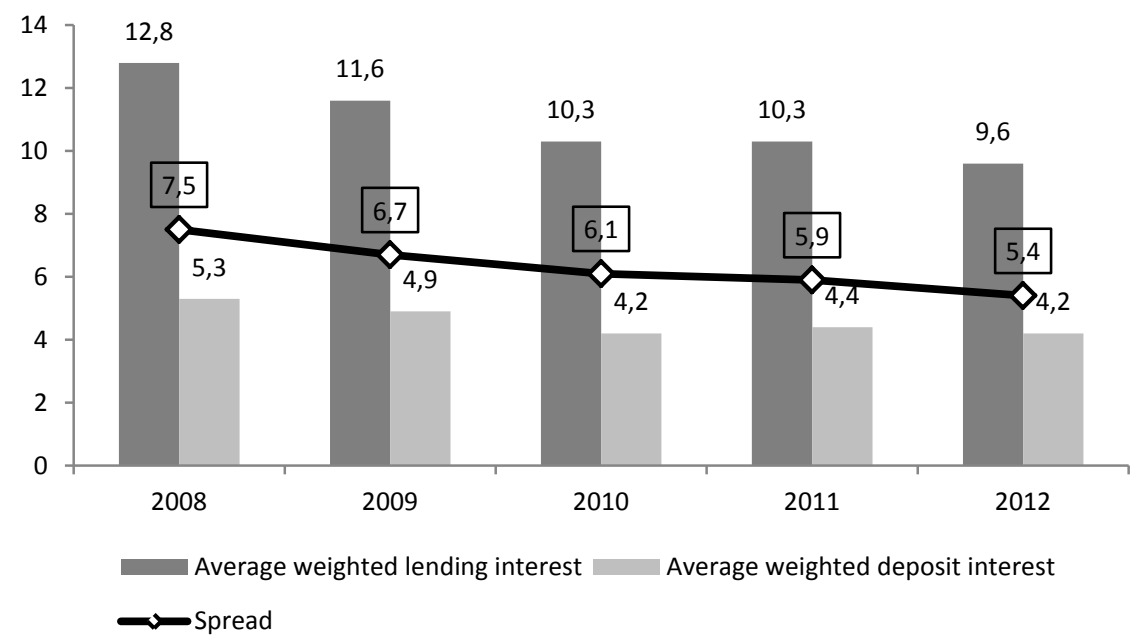

Source: Authors' calculations based on data from balance sheets of commercial banks

\section{Empirical Results of Research and Discussion}

Profitability of banking sector was measured on the one hand by calculation of ROA and ROE ratios, and on the other hand by calculation of profit margins, including net interest gain, net fees and commissions gain and net pre-tax result to total revenue ratios.

\subsection{Return on Assets and Return on Equity Ratios}

The values of the most commonly used profitability ratios, return on assets (ROA) and return on equity (ROE), confirm the conclusions of the empirical analysis of the net pre-tax result of the banking sector in Serbia during the period from 2008 till 2012 (Fig. 7). The highest value of return on assets ratio was achieved in 2008, when ROA amounted to $2.1 \%$. In the next two years the level of ROA amounted to around 1\%. After a barely positive result in 2011, ROA increased in 2012 to the level of $0.43 \%$.

The value of return on equity ratio followed the dynamics of return on assets ration during the entire observed period. In 2008, ROE amounted to even 9.3\%. During the first wave of world economic crisis in 2009 and 2010, it amounted to around 5\%, while in 2012 ROE was at the level of $2.05 \%$. 
Miljković M. et al.: Profitability of Serbian Banking Sector during global economic crisis

Figure 7. ROA and ROE of the Serbian banking sector during 2008-2012, in $\%$

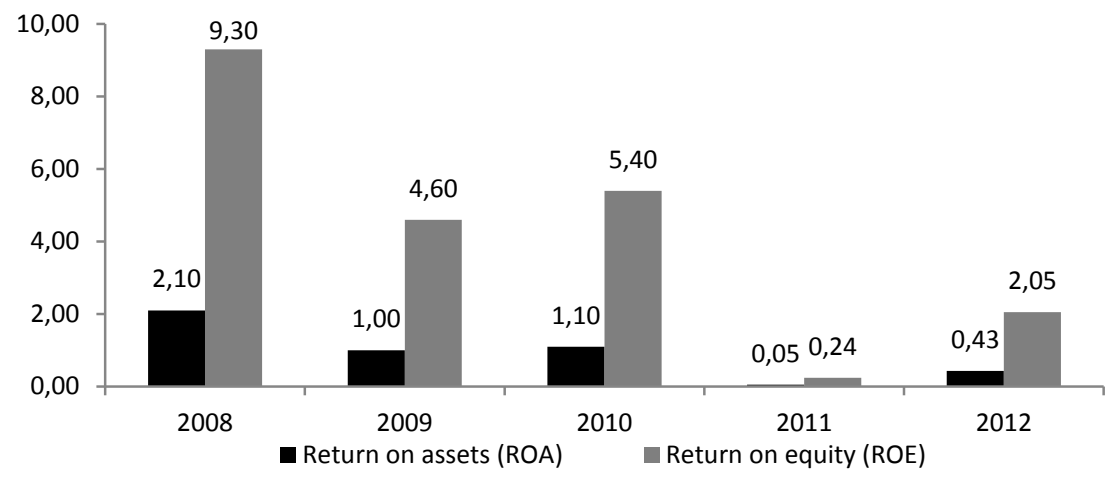

Source: Banking Sector in Serbia -Quarter Reports, National Bank of Serbia

When observed by 15 largest banks according to the total assets criterion, 10 commercial banks achieved the above-average value of return on assets ratio in 2012 (Fig. 8). Raiffeisen Banka and Procredit Bank were characterized by the highest values of ROA, reaching the level of 3.11\% in 2012. On the other hand, the lowest value of ROA was achieved by Alpha Bank, minus 3.26\%.

Figure 8. Return on assets ratio in 2012 by 15 largest commercial banks, in \%

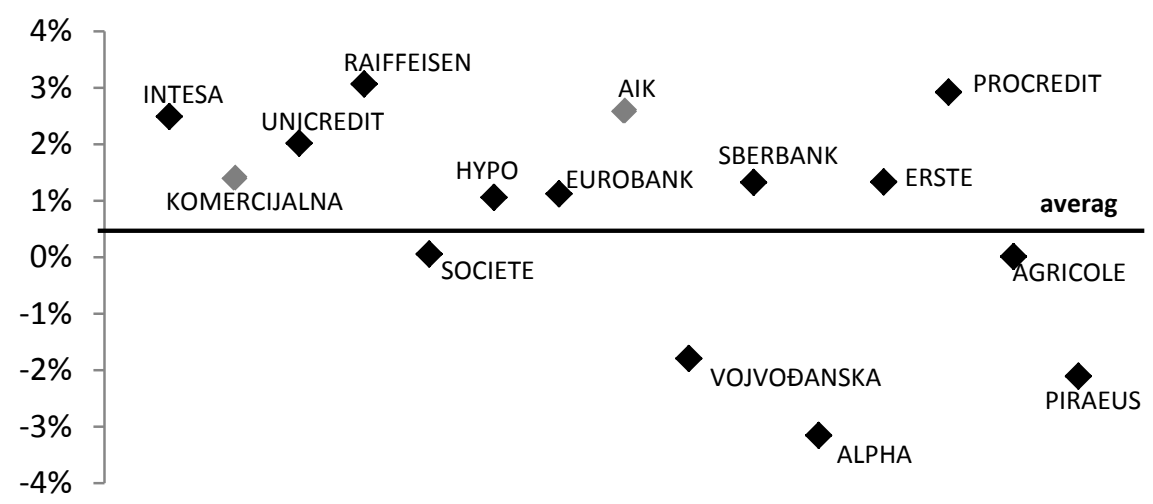

Source: Authors' calculations based on data from balance sheets of commercial banks

The similar results are obtained when analysing the values of return on equity ratio by the largest banks in the Serbian banking sector (Fig. 9) Also $10 \mathrm{com}$ mercial banks achieved the above-average value of return on equity ratio in 2012. Procredit Bank was characterized by the highest value of ROE, reaching the level of $18.49 \%$ in 2012, while Banca Intesa, Unicredit Bank and Raif- 
Miljković M. et al.: Profitability of Serbian Banking Sector during global economic crisis

feisen Banka achieved the value of more than $10 \%$. On the other hand, the lowest value of ROE was achieved by Alpha Bank, even minus $24.61 \%$.

Figure 9. Return on equity ratio in 2012 by 15 largest commercial banks, in \%

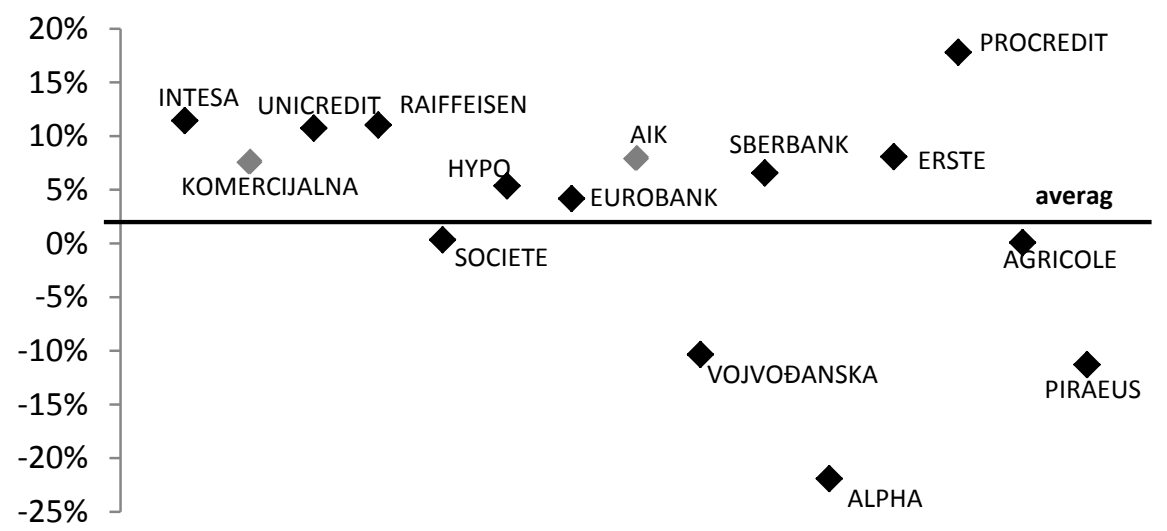

Source: Authors' calculations based on data from balance sheets of commercial banks

\subsection{Net Profit Margins}

The analysis of net profit margins of the banking sector in Serbia showed different trends (Fig. 10). On the one hand, net pre-tax profit as percentage of total revenue completely followed the dynamics of the other profitability ratios, such as ROA and ROE, during the entire observed period, while on the other hand, net interest gain and net fees and commissions gain as percentage of total revenue indicated different trend.

Unlike net pre-tax profit, net interest gain was more stable during the analyzed period. In 2009, the first year of economic crisis in Serbia, the share of net interest gain in total revenue of the banking sector as a whole was even at a higher level as compared with the previous year and amounted to 53\%, indicating that a declining profit in the banking sector was not caused by lower interest gain. The value of net fees and commissions gain was also stable at the level of around $15 \%$ during the observed period, indicating relative lower significance of fees and commissions gain as compared with interest gain. 
Figure 10. Profit margins of the banking sector in Serbia during 2008-2012, as percentage of total revenue

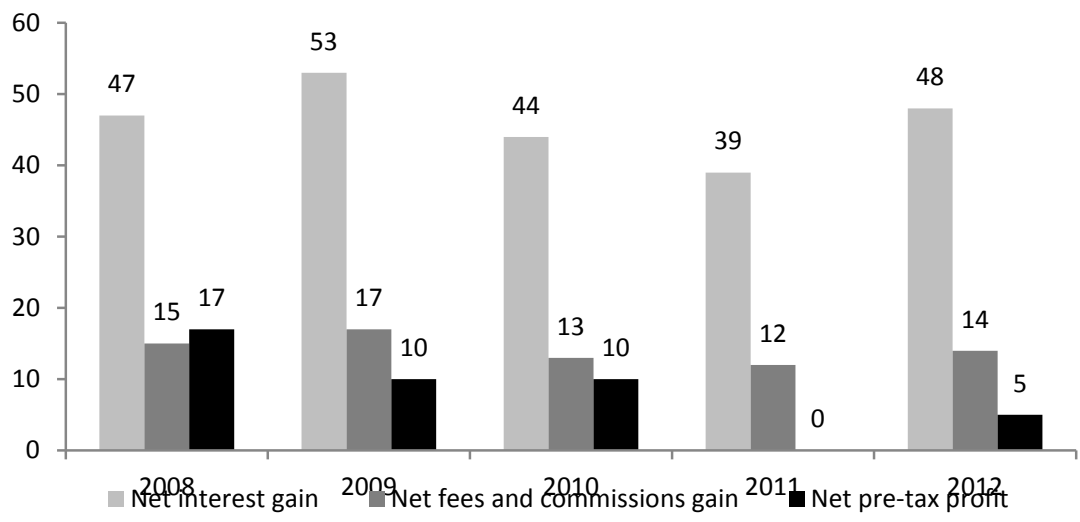

Source: Authors' calculations based on data from balance sheets of commercial banks

When observed by 15 largest banks according to the total assets criterion (Fig. 11), 6 commercial banks achieved the above-average value of net interest gain as percentage of total revenue in 2012. Other 6 banks achieved results at the level of sectoral average, while only 3 banks showed belowaverage performances. Sberbank was characterized by the highest value of net interest gain in 2012, reaching the level of $57.58 \%$ of total revenue. On the other hand, the lowest value of net interest gain was achieved by Piraeus Bank, 12.44\% of total revenue.

Figure 11. Net interest gain in 2012 by 15 largest commercial banks, as percentage of total revenue

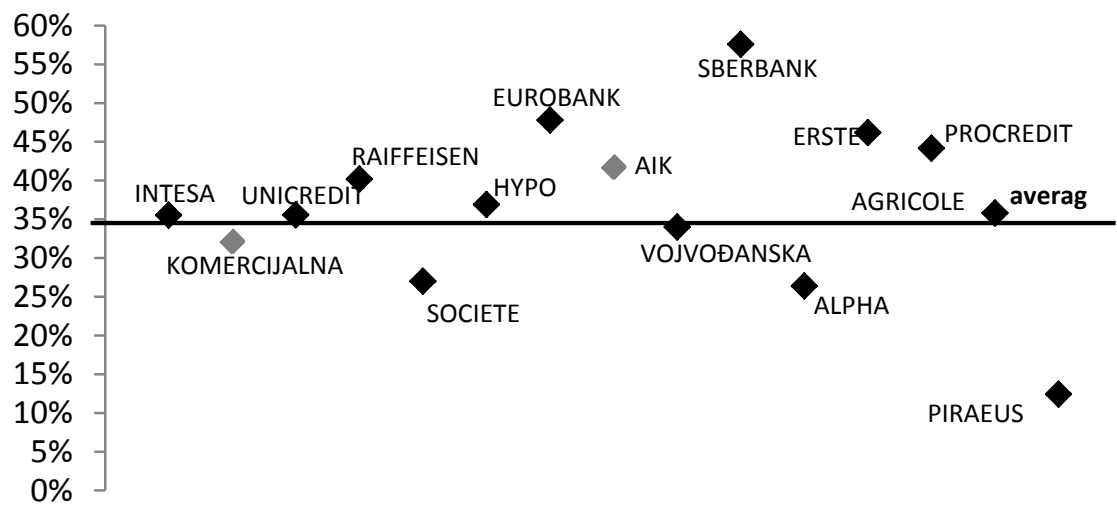

Source: Authors' calculations based on data from balance sheets of commercial banks 
The analysis of net fees and commissions gain as percentage of total revenues by 15 largest commercial banks (Fig. 12), showed that even 8 banks achieved below-average results in 2012, including the most profitable banks such as Banca Intesa and Unicredit Bank, indicating that income from fees and commissions has much more impact on business results of smaller banks, while the bigger ones are more focused to achieve higher interest income

Figure 12. Net fees and commissions gain in 2012 by 15 largest commercial banks, as percentage of total revenue

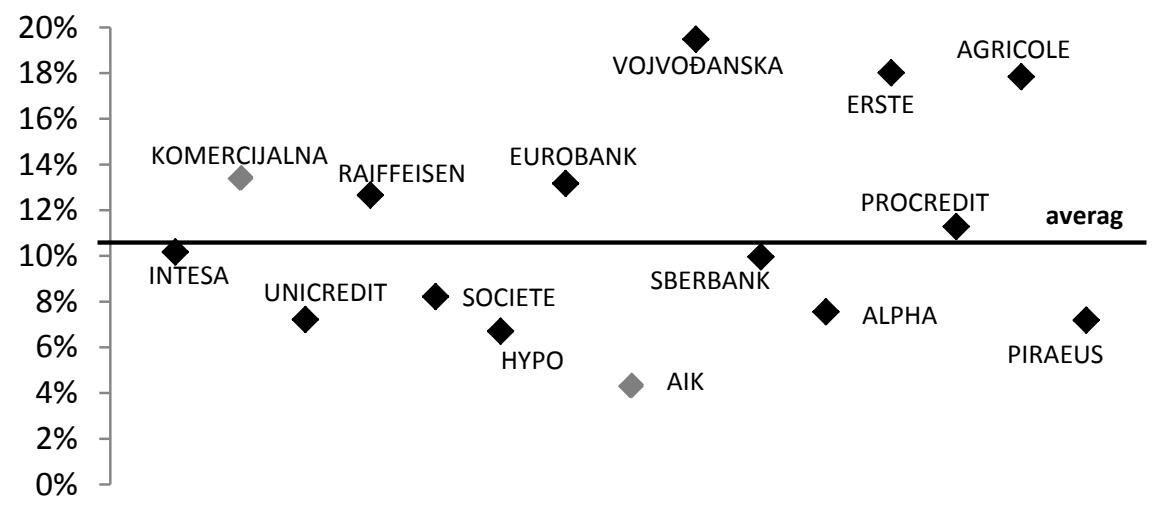

Source: Authors' calculations based on data from balance sheets of commercial banks

When observed by net pre-tax profit/loss as percentage of total revenue (Fig. 13), the best results achieved the most profitable banks, such as Raiffeisen Banka, Banca Intesa, AIK Banka, Sberbank, Unicredit Bank etc. It is interesting that there are some commercial banks, such as Vojvodjanska Banka, which operated with losses, but at the same time net interest gain and net fees and commissions gain as percentage of total revenue of this bank were above sectoral average, indicating that net losses were not caused by low level of interest gain, then rather by other factors. This and other banks with similar performances actually need to increase their cost-effectiveness on the one hand and to increase the volume of their activities on the other hand in order to move to the positive level of profitability. 
Figure 13. Net pre-tax profit/loss in 2012 by 15 largest commercial banks, as percentage of total revenue

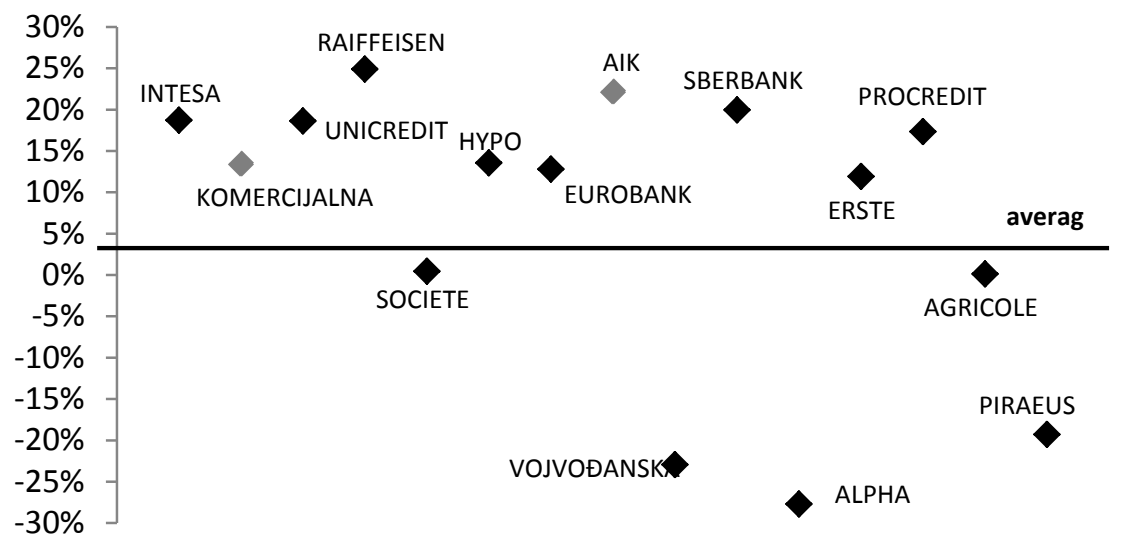

Source: Authors' calculations based on data from balance sheets of commercial banks

\section{Conclusions}

This paper contributes to the topic of pro-cyclicality of bank profitability. Spill over effects of the global economic crisis on Serbian banking sector were for the first time transmitted in 2009, considering strong decrease of net pre-tax profit. The research showed that one of the most important factors contributing to declining trend of net pre-tax result of commercial banks in the observed period includes an increase of net operating expenses, especially expenses on account of a write-off of uncollected claims. The empirical data indicated increase of NPL for the whole analyzed period as a direct consequence of fast credit growth in the pre-crisis period, considering that real sector fell into recession.

Measuring profitability based on selected criteria, the research achieved the following results for Serbian banking sector:

- The distributions of profit and losses are highly concentrated;

- The values of ROA and ROE confirm the conclusions of the analysis of the net pre-tax result;

- Net pre-tax profit as percentage of total revenue completely followed the dynamics of ROA and ROE, while net interest gain and net fees and commissions gain as percentage of total revenue indicated different trend - these ratios were more stable and showed that a declining profit was not caused by lower interest gain and fees and commissions gain; 
- Income from fees and commissions has much more impact on business results of smaller banks, while the bigger ones are more focused to achieve higher interest income;

- Banks operating with losses need to increase their cost-effectiveness or the volume of their activities in order to move to the positive level of profitability;

- Certain impact on declining banking profitability was produced by declining interest spread trend.

It seems that prospects for further profit growth are modest. Serbian banks may remain considerably less profitable than prior to the crisis, considering that the growth drivers of both the boom years until 2007 and the post-crisis rebound will probably not be able to bring a significant further improvement in the medium term period.

\section{References}

Agoraki, M., Delis, M.D., \& Pasiouras, F. (2011). Regulations, competition and bank risk-taking in transition countries. Journal of Financial Stability, 7(1), 38-48.

Agusman, A., Monroe, G.S., Gasbarro, D., \& Zumwalt, J.K. (2008). Accounting and capital market measures of risk: evidence from Asian banks during 1998-2003. Journal of Banking and Finance, 32(4), 480-488.

Albertazzi, U., \& Gambacorta, L. (2009). Bank profitability and the business cycle. Journal of Financial Stability, 5(4), 393-409. doi:10.1016/j.jfs.2008.10.002

Alper, D., \& Anbar, A. (2011). . Business and Economics Research Journal, 2(2), 139152.

Altunbas, Y., Carbo, S., Gardener, E.P.M., \& Molyneux, P. (2007). Examining the Relationships between Capital, Risk and Efficiency in European Banking. European Financial Management, 13(1), 49-70. doi:10.1111/j.1468036X.2006.00285.X

Athanasouglou, P.P., Delis, M.D., \& Staikouras, C.K. (2006). Determinants of bank profitability in the Southeastern European region. Bank of Greece. Working Paper br. 47.

Athanasoglou, P.P., Brissimis, S.N., \& Delis, M.D. (2008). Bank-specific, industryspecific and macroeconomic determinants of bank profitability. Journal of International Financial Markets, Institutions and Money, 18, 121-136.

Bolt, W., Haan, L., Hoeberichts, M., Oordt, M., \& Swank, J. (2010). Bank Profitability during Recessions. De Nederlandsche Bank.. Working Paper No. 251.

Carbo, S., Humphrey, D., Maudos, J., \& Molyneux, P. (2009). Cross-country comparisons of competition and pricing power in European banking. Journal of International Money and Finance, 28(1), 115-134.

de Guevara, F.J., Maudos, J., \& Pérez, F. (2007). Integration and competition in European banks. Journal of International Money and Finance, 26(1), 26-45.

Filipović, S. (2010). Effects of Global Financial Crisis on the Financial Sector of Serbia. Industrija, 38(3), 79-94. 
Goddard, J.A. (2004). Dynamics of Growth and Profitability in Banking. Journal of money credit and banking, 36(6), 1069-1090. doi:10.1353/mcb.2005.0015

Hoffmann, P.S. (2011). Determinants of the Profitability of the US Banking Industry. International Journal of Business and Social Science, 2(22),

Iannotta, G., Nocera, G., \& Sironi, A. (2007). Ownership structure, risk and performance in the European banking industry. Journal of Banking and Finance, 31(7), 2127-2149.

Lee, C.C., \& Hsieh, M. (2013). The impact of bank capital on profitability and risk in Asian banking. Journal of International Money and Finance, 32, 251-281.

Lee, S.W. (2013). Financial Crisis, Regulatory Changes and Bank Profit. Review of European Studies, 5(5),

Lindblom, T., Olsson, M., \& Willesson, M. (2011). Financial Crisis and Bank Profitability, Bank Performance. In P. Molyneux (Ed.), Risk and Firm Financing. Palgrave Macmillan.

Miljković, M., Filipović, S., \& Tanasković, S. (2013). Market concentration in the banking sector - Evidence from Serbia. Industrija,

Monea, M. (2011). Analysis of Incomes, Expenses and Profitability in Banks. Annals of the University of Petrosani-Economics,

-National Bank of Serbia. . Balance Sheets and Income Statements of Commercial Banks. Retrieved from http://www.nbs.rs/internet/cirilica/50/50_5.html.

-National bank of Serbia. (2012). Banking Sector in Serbia - Fourth Quarter Report.

-National bank of Serbia. (2011). Banking Sector in Serbia - Fourth Quarter Report.

-National bank of Serbia. (2010). Banking Sector in Serbia - Fourth Quarter Report.

-National bank of Serbia. (2009). Banking Sector in Serbia - Fourth Quarter Report.

-National bank of Serbia. (2008). Banking Sector in Serbia - Fourth Quarter Report.

Radulescu, M., \& Tanascovici, M. (2012). Profitability of the CEE banking systems during the crisis period, Annals of the University of Petroşani. Economics, 12(1), 274-291.

-Raiffeisen Bank. (2013). Raiffeisen Research, CEE Banking Sector Report.

Swamy, W. (2013). Determinants of Bank Asset Quality and Profitability - An Empirical Assessment. Hyderabad: IBS.

Waheed, A., \& Younus, N. (2010). Effects of Financial Sector's Development and Financial Sector's Efficiency on Economic Growth: Empirical Evidence from Developing and Developed Countries. International Journal of Economic Perspectives, 4(2), 449-458. 